\title{
SŁOWNICTWO SPECJALISTYCZNE W NAUCZANIU JEZZYKA SLOWEŃSKIEGO JAKO OBCEGO NA KIERUNKU LINGWISTYKA DLA BIZNESU
}

\begin{abstract}
Słowa kluczowe: lingwistyka dla biznesu, nauczanie języka słoweńskiego, słownictwo specjalistyczne, słowenistyka

Streszczenie. Celem referatu jest przedstawienie sposobów nauczania słoweńskiego języka specjalistycznego na nowo otwartym na Uniwersytecie Łódzkim kierunku lingwistyka dla biznesu. Studiując go, studenci poznają słownictwo specjalistyczne z trzech dziedzin: logistyki, finansów i informatyki. Ponieważ ani na rynku słoweńskim, ani na polskim nie istnieją gotowe pomoce naukowe, na podstawie których można by było przeprowadzić tego typu zajęcia, autorka artykułu prezentuje materiały alternatywne, pozyskane z takich źródeł jak gazety i czasopisma, Internet i podręczniki do szkół zawodowych. Ponadto, w ostatniej części artykułu został przedstawiony program całego kierunku lingwistyka dla biznesu.
\end{abstract}

W dobie globalizacji, aby być konkurencyjnym na rynku pracy, należy nabyć wiele umiejętności. Do tradycyjnych zadań szkół wyższych należy kształcenie oraz prowadzenie badań naukowych, jednak coraz częściej uniwersytety nakładają na siebie trzeci cel - budowanie relacji z przedsiębiorstwami oraz sektorem publicznym i pozarządowym w celu przystosowania absolwentów do wymagań rynku pracy. Poprzez kontakty z potencjalnymi pracodawcami uczelnie wyższe mogą tworzyć programy dydaktyczne, dzięki którym studenci nie tylko zyskają niezbędną wiedzę teoretyczną, lecz także przekonają się, jak tę teorię wykorzystać w praktyce.

Wychodząc naprzeciw wymaganiom rynku, Uniwersytet Łódzki utworzył nowy kierunek: lingwistyka dla biznesu, na którym młodzi ludzie uczą się podstaw rachunkowości i finansów, wybranych aspektów prowadzenia biznesu oraz zapoznają się z dziedzinami takimi jak komunikacja interkulturowa, pragmatyka językowa i lingwistyka stosowana. Studia te pozwalają także na uzyskanie wyso-

*katarzyna.bednarska@uni.lodz.pl, Katedra Filologii Słowiańskiej, Wydział Filologiczny, Uniwersytet Łódzki, ul. Pomorska 171/173, 90-236 Łódź. 
kiej kompetencji językowej z dwóch języków obcych: wybranego języka europejskiego (dotychczas do wyboru były francuski, niemiecki, włoski, słoweński, hiszpański, w kolejnym roku zaś będzie można studiować chorwacki) i angielskiego. Języki te powinny zostać opanowane na poziomie powyżej B2 zgodnie z normami Europejskiego Systemu Opisu Kształcenia Językowego. Oprócz ćwiczeń lektoratowych studenci uczestniczą także w takich zajęciach jak gramatyka funkcjonalna, kultura danego obszaru językowego czy tłumaczenia. W ramach trzech przedmiotów poznają także odmiany specjalistyczne języków: język finansów i HR (II rok, semestr zimowy), język logistyki (II rok, semestr letni) oraz język IT (III rok, semestr zimowy). Zajęcia te prowadzone są w wymiarze 30 godzin. Na początku studenci posługują się językiem na różnych poziomach, w zależności od wybranego profilu, np. osoby, które postanowiły uczyć się języka niemieckiego, są na wyższym poziomie niż osoby studiujące język słoweński. Ma to związek z faktem, iż ci pierwsi przychodzą na studia już z pewną znajomością niemieckiego, podczas gdy ci drudzy słoweńszczyzny na pierwszym roku w ogóle nie znają.

Referat ma na celu przedstawienie praktyki nauczania wymienionych odmian języka słoweńskiego oraz zaprezentowanie materiałów używanych do pogłębiania wiedzy studentów.

Koncept nauczania języków obcych w konkretnych, specjalistycznych celach jest skomplikowanym problemem, ponieważ trudno określić granice nauczanych odmian języka, a niekiedy także wybrać odpowiednią metodę nauczania. Po trzyletnich studiach lingwistyczno-biznesowych studenci powinni być w stanie płynnie posługiwać się słownictwem specjalistycznym. Ponieważ zaczynają studia bez znajomości języka słoweńskiego, w pierwszych dwóch semestrach słownictwo biznesowe wprowadzane jest jedynie w ramach lektoratu (łącznie 252 godziny zajęć), głównie za pomocą stosującego metodę komunikacyjną podręcznika Poslovna slovenščina (poziom A1). Książka ta pomaga w nauce specjalistycznych słów, jednak już po kilku tygodniach staje się dla Polaków za łatwa, jest bowiem skierowana do wszystkich dorosłych osób pragnących uczyć się języka słoweńskiego, niezależnie od ich języka ojczystego. Polszczyzna i słoweńszczyzna należą natomiast do jednej rodziny językowej i są do siebie na tyle zbliżone, że polskim studentom bez trudu przychodzi zrozumienie większości treści zawartych w omawianym podręczniku. Na rynku słoweńskim nie ma jednak innej pomocy dydaktycznej, która ułatwiłaby pracę zarówno studentom, jak i wykładowcom kierunków biznesowych.

Zatem aby przekazać tego typu wiedzę, lektorzy muszą sięgać po inne źródła - oryginalne teksty z gazet i czasopism ekonomicznych, audycje, filmy, statystyki itp.

Nauczanie języka specjalistycznego jest ukierunkowane na przekazywanie konkretnych umiejętności, które będą niezbędne uczniom. W tym przypadku są to rozumienie i tworzenie tekstów ekonomicznych, logistycznych, informatycznych itp., bezproblemowa komunikacja oraz tłumaczenia. Ponieważ program lingwistyki dla biznesu nie jest stricte nastawiony na translatorykę, studenci uczą 
się dwutorowo - najpierw opanowują język obcy na tyle, aby być w stanie płynnie się w nim komunikować. Aby to osiągnąć, lektorzy najczęściej stosują metodę komunikacyjną (którą narzucają najnowsze podręczniki ogólne do nauczania języka słoweńskiego jako obcego), dzięki której poznawane są reguły gramatyczne, słownictwo ogólne, słoweńska kultura oraz elementy słownictwa specjalistycznego, czyli podstawy, bez których przyswajanie bardziej zaawansowanego materiału nie byłoby możliwe. Kolejnym krokiem jest zapoznanie studentów z tekstami specjalistycznymi (termin tekst specjalistyczny został tu zastosowany w odniesieniu do tekstów związanych z przyszłą karierą studentów i ich zainteresowaniami, nie oznacza więc zaawansowanych tekstów akademickich). Pomocna okazuje się metoda thumaczeniowa, jednak niewątpliwie nie można jej nadużywać. Kolejna metoda - CLIL - zostanie opisana w dalszej części artykułu.

Lingwistyka dla biznesu jest nowym kierunkiem, w związku z czym sylabusy i dokładne programy zajęć są dopiero tworzone. Autorka niniejszego artykułu była pierwszą osobą prowadzącą zajęcia z języka specjalistycznego w grupie słoweńskiej, dlatego mogła pozwolić sobie na dostosowanie programu do konkretnych potrzeb studentów. Dlatego w programach poszczególnych przedmiotów znalazły się takie zagadnienia jak: gospodarka Słowenii i Polski, giełda, podatki, inflacja i deflacja, kapitał, zasoby ludzkie (przedmiot Język specjalistyczny HR i finansów), rodzaje logistyki, rodzaje transportu, logistyka w małych, średnich i dużych przedsiębiorstwach, outsourcing, dokumenty transportowe i spedycyjne (przedmiot Język specjalistyczny logistyki), części komputera, rodzaje oprogramowania, systemy operacyjne, pakiet Office, tworzenie stron internetowych, aplikacje mobilne (przedmiot Język specjalistyczny IT).

Podstawę zajęć Język specjalistyczny HR i finansów, Język specjalistyczny logistyki oraz Język specjalistyczny IT stanowią teksty wyekscerpowane z oryginalnych słoweńskich źródeł - czasopism specjalistycznych, podręczników akademickich itp. W dzisiejszych czasach dobrym źródłem materiałów jest także Internet, dostarczający interesujących artykułów na każdy niemal temat. Teksty te są przez wykładowców upraszczane i przystosowywane do poziomu zaawansowania językowego studentów. Muszą być ponadto relewantne z punktu widzenia rodzaju sytuacji, celu komunikacji etc., jak również przydatne dla studenta w kontekście jego przyszłej komunikacji. Różnią się jednak od tekstów zawartych w ogólnych podręcznikach do nauczania języka słoweńskiego, z którymi studenci mają do czynienia podczas lektoratu. Różnica tkwi przede wszystkim w nasyceniu tekstu terminologią. Oprócz tego materiał musi zawierać informacje (zarówno leksykalne, jak i gramatyczne), które studenci już poznali, dzięki czemu wykorzystają je do zapoznania się z nowym tekstem.

Teksty specjalistyczne zwykle są więc autentyczne, co pomaga studentom obserwować docelową kulturę i komunikację obcojęzyczną. Za przykład może posłużyć materiał dotyczący współpracy gospodarczej między Polską i Słowenią, 
pozyskany ze strony ambasady Słowenii w Warszawie (http:/varsava.veleposlanistvo.si/index.php?id=4026) i dostosowany do poziomu studentów. Materiał ten został wprowadzony w połowie trzeciego semestru nauki słoweńskiego. Ponieważ podczas równoległych zajęć lektoratowych studenci powtarzali słoweńskie przypadki, z tekstu zostały usunięte wybrane końcówki rzeczowników i czasowników. Materiał służył ponadto jako powtórka liczebników oraz wprowadzenie procentów.

\section{Gospodarsko sodelovanje}

Poljska sodi med pomembnejše zunanjetrgovinske partnerice Slovenije. Na gospodarsk...... področj....... sta državi podpisali vse pomembnejš....... sporazum.......:

- Konvencijo o izogibanju dvojnega obdavčevanja v zvezi z davki od dohodka in premoženja,

- Sporazum o gospodarskem sodelovanju,

- Sporazum o vzajemnem spodbujanju in zaščiti investicij,

- Sporazum o znanstvenem in tehnološkem sodelovanju.

Blagovna menjava med Slovenijo in Poljsko je v letu 2008 znašala 1,1 milijarde EUR, kar pomeni 2,6 odstotk celotne menjave Slovenije s svet....... (8. mesto med zunanjetrgovinskimi partnericami). Zaradi svetovn....... gospodarsko-finančn....... kriz....... se je v prvih petih mesecih 2009 obseg blagovne menjave zmanjšal za 35 odstotkov. Izvoz je bil v tem obdobju manjši za 41, uvoz pa za 24 odstotk........ v primerjavi z enakim obdobjem 2008.

Med januar....... in avgust...... 2009 je blagovna menjava znašala 529,89 milijona EUR, izvoz iz Slovenije na Poljsko je dosegel 307,4 milijona EUR, uvoz iz Poljske pa 222,5 milijona EUR.

V letu 2010 se je slovenski izvoz na Poljsko povečal za kar 34,4\%, obseg bilateraln blagovn menjav. med državama pa se je povečal za $26,4 \%$ in z 1,046 mlrd evrov spet dosegel visoko raven pred izbruhom gospodarske krize v letu 2008.

Najpomembnejši izvozni izdelki na Poljsko ostajajo zdravila, osebni avtomobili in drug....... motorn....... vozil....... za prevoz ljudi ter deli za avtomobilsko industrijo.

Aby urozmaicić zajęcia, po przeczytaniu i uzupełnieniu tekstu, wprowadzono zadania dodatkowe - stymulowane sytuacje komunikacyjne (projekt i odgrywanie ról) oraz krótką debatę.

\section{Projekt i debata}

Studenci zostali podzieleni na trzy grupy trzyosobowe. Zadaniem każdej z grup było stworzenie profilu polskiego przedsiębiorstwa - należało zastanowić się nad takimi kwestiami jak specjalizacja, budżet, finansowanie, rodzaj spółki, 
konkurencyjność, nazwa itp. Następnie każda grupa przedstawiała swoje przedsiębiorstwo pozostałym studentom.

Kolejnym krokiem była debata, w wyniku której wyłoniono firmę, która wg studentów najlepiej prosperowałaby na rynku słoweńskim ${ }^{1}$. Studenci wybrali przedsiębiorstwo produkujące krasnale ogrodowe.

Podczas debaty studenci stanęli wobec pewnego realnego problemu, który najpierw przedyskutowali, przedstawili alternatywy, a następnie rozwiązali, uzasadniając swą decyzję.

\section{Odgrywanie ról}

Studenci zostali podzieleni na dwie grupy - „polską” i „,łłoweńską”. Pierwsza składała się z przedstawicieli polskiego przedsiębiorstwa produkującego krasnale ogrodowe, druga zaś z potencjalnych słoweńskich odbiorców krasnali, czyli przedstawicieli firmy ogrodniczej. Zadaniem studentów było przygotowanie się do rozmowy biznesowej, a następnie odbycie jej.

Za pomocą tych ćwiczeń studenci utrwalają słownictwo związane $\mathrm{z}$ handlem międzynarodowym, np. takie słowa jak import (słn. uvoz), eksport (słn. izvoz), produkt (słn. izdelek), popyt (słn. povpraševanje). Odgrywane role odnoszą się do realnych sytuacji, w jakich w przyszłości mogą się znaleźć studenci Lingwistyki dla biznesu. Zadania wymagają od nich sięgania zarówno po ogólne kompetencje językowe, jak i po język specjalistyczny, czyli komunikowania się w celu osiągnięcia pewnego celu.

Ostatnim elementem zajęć dotyczących współpracy gospodarczej między Polską a Słowenią było zadanie pracy domowej - ćwiczenia translatorycznego. Studenci zostali poproszeni o odszukanie w portalu Eur-Lex polskich odpowiedników nazw porozumień i konwencji wymienionych w tekście podstawowym². Ćwiczenie to nie zostało przeprowadzone podczas zajęć ze względu na odtwórczy charakter.

Urozmaicenie zajęć teoretycznych jest koniecznością. Gry symulacyjne pozwalają uczącym się wejść w role, z którymi mogą mieć do czynienia w przyszłej pracy, a ponadto wymagają od nich użycia różnych sprawności językowych, co przyczynia się do lepszego, wielotorowego zapamiętania materiału. Oprócz tego studenci „na sucho” ćwiczą komunikację interkulturową, dzięki czemu mają możliwość skonfrontowania kultury słoweńskiej z rodzimą, a co za tym idzie - mogą zapobiec ewentualnym nieporozumieniom. Kolejną zale-

${ }^{1}$ Studenci drugiego roku lingwistyki dla biznesu są dobrze zaznajomieni ze słoweńską sytuacją gospodarczą i słoweńską kulturą, jak również uczestniczyli w zajęciach nauka o komunikacji i komunikacja międzykulturowa, są więc w stanie wypowiedzieć się na temat potrzeb słoweńskiego rynku.

${ }^{2}$ Przed zadaniem pracy domowej studentów zapoznano z podstawowymi portalami ułatwiającymi pracę tłumacza oraz nauczono ich wyszukiwania odpowiedników terminów, nazw itp. 
tą ćwiczeń komunikacyjnych jest rozwijanie kreatywności, umiejętności pracy w grupie, oraz podejmowania decyzji, co jest elementem większości przedmiotowych sylabusów.

Ponieważ całe zajęcia, a zatem zarówno opracowywanie tekstu głównego, jak i ćwiczenia komunikacyjne, przebiegają w języku obcym, można je porównać do zajęć przeprowadzanych metodą CLIL (nauczanie przez treść), rekomendowaną przez Unię Europejską:

Content and Language Integrated Learning (CLIL), in which pupils learn a subject through the medium of a foreign language, has a major contribution to make to the Union's language learning goals. It can provide effective opportunities for pupils to use their new language skills now, rather than learn them now for use later. It opens doors on languages for a broader range of learners, nurturing self-confidence in young learners and those who have not responded well to formal language instruction in general education. It provides exposure to the language without requiring extra time in the curriculum, which can be of particular interest in vocational settings.

(http://eur-lex.europa.eu/legal-content/EN/TXT/?uri=celex\%3A52003DC0449)

Jak zauważa Maria Dakowska (2001, s. 124), ważnym elementem nauczania przez treść jest nie tylko użycie języka obcego do zdobywania wiedzy, ale także rozwijanie ogólnych umiejętności językowych:

Koncepcja ta eliminuje tradycyjny podział na zajęcia językowe i inne przedmioty, z którymi mamy na ogół do czynienia. Do korzyści, które płyną z takich priorytetów, zaliczyć należy skorelowanie wybranego do nauki materiału z potrzebami i zainteresowaniami uczniów, tak aby prezentowane treści były dla studenta istotne i tym samym motywujące, odwołujące się do jego dotychczasowej wiedzy (Dakowska 2001, s. 125).

Dakowska dodaje, iż użyte podczas zajęć materiały dydaktyczne powinny zawierać teksty autentyczne i dłuższe jednostki dyskursu. Oczywiście wymaga to od nauczyciela większego nakładu pracy niż ma to miejsce w przypadku pracy z gotowym podręcznikiem, jednak efekty są widoczne.

W podobny sposób zostały zrealizowane zajęcia z przedmiotu Język specjalistyczny logistyki dotyczące rodzajów transportu. Pierwszym ich elementem było zapoznanie się przez studentów z nazwami środków transportu oraz ich charakterystyką. Dwa tygodnie przed zajęciami dwie osoby zostały poproszone o stworzenie prezentacji na ten temat (dodatkowa praca domowa wynikała z odrabiania nieobecności). Studenci przedstawili kilka rodzajów transportu: ciężarowy, kolejowy, powietrzny i wodny. Pozostałe osoby miały za zadanie skupić się na takich walorach jak szybkość, bezpieczeństwo, zbiorowość, dokładność, dostępność, użyteczność, ochrona środowiska. Następnie przeprowadzona została debata, podczas której studenci oceniali poszczególne środki transportu pod kątem danych cech, a ochotnik uzupełniał tabelę punktami (1 - ocena najniższa, 4 - ocena najwyższa): 


\begin{tabular}{|l|l|l|l|l|}
\cline { 2 - 5 } \multicolumn{1}{c|}{} & \multicolumn{1}{c|}{ Kamion } & Vlak & Letalo & Ladja \\
\hline Hitrost & & & & \\
\hline Varnost & & & & \\
\hline Množičnost & & & & \\
\hline Točnost & & & & \\
\hline Dostopnost & & & & \\
\hline Udobnost & & & & \\
\hline Varstvo okolja & & & & \\
\hline SKUPAJ TOČK & & & & \\
\hline
\end{tabular}

Ćwiczenie, oprócz utrwalania słownictwa związanego z transportem, miało na celu przypomnienie stopniowania przymiotników - studenci tworzyli zdania typu Menim, da je letalo hitrejše kot vlak (Uważam, że samolot jest szybszy od pociagu). Ponadto studenci musieli na głos sumować punkty, dzięki czemu przypomnieli sobie liczebniki.

Jeśli chodzi o zajęcia specjalistyczne związane z językiem IT, najlepiej byłoby, gdyby studenci mieli dostęp do komputerów z oprogramowaniem w danym języku obcym. Dzięki temu mogliby na żywo ćwiczyć najważniejsze zagadnienia, takie jak obsługa poszczególnych systemów operacyjnych, pakietu Office etc. Niestety nie jest to możliwe, w związku z czym większość zajęć praktycznych prowadzona jest bez tego narzędzia. Część z nich może być wspomagana słoweńskim podręcznikiem Poslovna informatika, przeznaczonym dla studentów ekonomii. Pomoc ta jest jednak stosunkowo stara, ponieważ została wydana w 2000 roku, w związku z czym wiele zagadnień uległo zmianie. Niemniej podręcznik przydaje się do wprowadzania tematów związanych z programami Word, Excel, Powerpoint, Access oraz obsługą maila i Internetu. Ponadto w semestrze, w którym studenci uczęszczają na zajęcia z języka specjalistycznego IT, odbywają się także praktyki w firmach powiązanych z kierunkiem lingwistyka dla biznesu. Podczas praktyk większość studentów spotyka się ze słownictwem specjalistycznym, a następnie konsultuje się i dzieli swoimi wątpliwościami podczas zajęć.

Dzięki dużej liczbie zajęć lektoratowych (łącznie 642 godziny przez sześć semestrów), ćwiczeń z języka specjalistycznego (łącznie 90 godzin podczas trzech semestrów) oraz innym zajęciom prowadzonym w języku słoweńskim, jak na przykład kultura Słowenii (45 godzin), tłumaczenia specjalistyczne (56 godzin), gramatyka praktyczna (28 godzin), studenci lingwistyki dla biznesu szybko czynią postępy i znają słoweńszczyznę, zarówno specjalistyczną, jak i ogólną, na wysokim poziomie. Są w stanie podjąć pracę, w której wykorzystają swoje umiejętności, można więc powiedzieć, że trzeci cel kształcenia uniwersyteckiego został osiągnięty. 


\section{BIBLIOGRAFIA}

Baloh P., Vrečar P., 2000, Poslovna informatika. Priročnik za vaje, Lublana.

Dakowska M., 2001, Psycholingwistyczne podstawy dydaktyki języków obcych, Warszawa.

Volavšek Kurasch N., Rigler Šilc K., 2010, Poslovna slovenščina. Učbenik poslovne slovenščine kot tujega/drugega jezika za začetnike, Lublana.

http://eur-lex.europa.eu/legal-content/EN/TXT/?uri=celex\%3A52003DC0449, [02.03.2016].

Katarzyna Bednarska

\section{TEACHING SPECIALIST VOCABULARY AT THE LINGUISTICS FOR BUSINESS SPECIALIZATION}

Keywords: Linguistics for business, teaching Slovene as a foreign language, specialist vocabulary, Slovene studies

Summary. The aim of the article is to present the methods and techniques used for specialist content-based courses of Slovene language taught as a part of the newly launched study program at the University of Lodz - Linguistics for Business. The content of the courses focuses on three fields: logistics, finances and computer studies. Due to the lack of specially designed materials for teaching this type of courses the author will introduce her own alternative materials, collected from different sources such as newspapers and magazines, the Internet and textbooks for vocational education. A short overview of syllabi for Linguistics in Business will be taken. 